\title{
Loss of pain perception in diabetes is dependent on a receptor of the immunoglobulin superfamily
}

\author{
Angelika Bierhaus, ${ }^{1}$ Karl-Matthias Haslbeck, ${ }^{2}$ Per M. Humpert, ${ }^{1}$ Birgit Liliensiek, $, 1,3$ \\ Thomas Dehmer, ${ }^{4}$ Michael Morcos, ${ }^{1}$ Ahmed A.R. Sayed, ${ }^{1}$ Martin Andrassy, ${ }^{1,5}$ \\ Stephan Schiekofer, ${ }^{1}$ Jochen G. Schneider, ${ }^{1}$ Jörg B. Schulz, ${ }^{4}$ Dieter Heuss, ${ }^{2}$ \\ Bernhard Neundörfer, ${ }^{2}$ Stefan Dierl, ${ }^{6}$ Jochen Huber, ${ }^{6}$ Hans Tritschler, ${ }^{7}$ Ann-Marie Schmidt, ${ }^{5}$ \\ Markus Schwaninger, ${ }^{1}$ Hans-Ulrich Haering, ${ }^{4}$ Erwin Schleicher, ${ }^{4}$ Michael Kasper, ${ }^{8}$ \\ David M. Stern, ${ }^{9}$ Bernd Arnold, ${ }^{3}$ and Peter P. Nawroth ${ }^{1}$ \\ 1Departments of Medicine I and Neurology, University of Heidelberg, Heidelberg, Germany. ${ }^{2}$ Department of Neurology, \\ University of Erlangen-Nürnberg, Erlangen, Germany. ${ }^{3}$ Deutsches Krebsforschungszentrum, Heidelberg, Germany. \\ ${ }^{4}$ Departments of Medicine IV and Neurology, University of Tübingen, Tübingen, Germany. ${ }^{5}$ Columbia University, Department of Physiology, \\ New York, New York, USA. ${ }^{6}$ Aventis Pharma GmbH, Frankfurt am Main, Germany. ${ }^{7}$ VIATRIS GmbH \& Co. KG, Frankfurt am Main, Germany. \\ ${ }^{8}$ Department of Anatomy, Technical University Dresden, Dresden, Germany. ${ }^{9}$ Medical College of Georgia, Augusta, Georgia, USA.
}

\begin{abstract}
Molecular events that result in loss of pain perception are poorly understood in diabetic neuropathy. Our results show that the receptor for advanced glycation end products (RAGE), a receptor associated with sustained NF- $\kappa B$ activation in the diabetic microenvironment, has a central role in sensory neuronal dysfunction. In sural nerve biopsies, ligands of RAGE, the receptor itself, activated NF- $\kappa B$ p 65 , and IL- 6 colocalized in the microvasculature of patients with diabetic neuropathy. Activation of NF- $\kappa B$ and NF- $\kappa B-d e p e n d e n t$ gene expression was upregulated in peripheral nerves of diabetic mice, induced by advanced glycation end products, and prevented by RAGE blockade. NF- $\kappa$ B activation was blunted in RAGE-null ( $\mathrm{RAGE}^{-/}$) mice compared with robust enhancement in strain-matched controls, even 6 months after diabetes induction. Loss of pain perception, indicative of long-standing diabetic neuropathy, was reversed in WT mice treated with soluble RAGE. Most importantly, loss of pain perception was largely prevented in $\mathrm{RAGE}^{-/-}$mice, although they were not protected from diabetes-induced loss of PGP9.5-positive plantar nerve fibers. These data demonstrate, for the first time to our knowledge, that the RAGE-NF- $\kappa B$ axis operates in diabetic neuropathy, by mediating functional sensory deficits, and that its inhibition may provide new therapeutic approaches.
\end{abstract}

\section{Introduction}

Neuronal dysfunction that leads to loss of pain perception triggers a cascade of events that finally results in nonhealing diabetic ulcers, a major cause of morbidity in patients with diabetes (1). Hyperglycemia triggers a number of mechanisms thought to underlie diabetic neuropathy (2), including generation of free radicals (3), activation of the polyol pathway (4), induction/activation of PKC (5), microvascular disease (6-10), aberrant regulation of neurotrophic factors (11), C-peptide deficiency (12), and formation of advanced glycation end products (AGEs) through nonenzymatic glycation (13). Although extensive accumulation of AGEs, in particular carboxymethyllysine (CML) adducts, has been described in peripheral nerves of patients with diabetes mellitus (13-15), functional effects of AGE deposition and AGE-mediated cellular signaling on neuronal dysfunction have not been defined.

Based on studies in a range of experimental models, neuronal dysfunction is closely associated with activation of NF- $\mathrm{KB}(16)$ and

Nonstandard abbreviations used: $A \beta$, amyloid- $\beta$ peptide; AGE, advanced glycation end product; CML, carboxymethyllysine; CMT, Charcot-Marie-Tooth disease; CMT-I, CMT type I; DRG, dorsal root ganglia; EMSA, electrophoretic mobility shift assay; PVD, peripheral vascular disease; RAGE, receptor for advanced glycation end products; sRAGE, soluble RAGE; STZ, streptozotocin.

Conflict of interest: The authors have declared that no conflict of interest exists.

Citation for this article: J. Clin. Invest. 114:1741-1751 (2004).

doi: $10.1172 / \mathrm{JCI} 200418058$ expression of proinflammatory cytokines, such as IL- 6 and TNF- $\alpha$ (16-18). For example, antioxidants, which suppress activation of NF-кB in vitro (19) and in diabetic patients in vivo (20), attenuate symptoms in somatic and autonomous neuropathies and ameliorate blood flow in some but not all clinical trials (21-23).

In view of previous observations indicating that ligation of the receptor for advanced glycation end products (RAGE) results in sustained activation of NF- $\mathrm{KB}$ (24), we considered the hypothesis that RAGE-ligand interaction might contribute to neuronal dysfunction and, ultimately, neuropathy in diabetes. A logical starting point for the cascade of events resulting in RAGE-mediated cellular activation would be hyperglycemia-induced overproduction of mitochondrial superoxide, eventuating in $\operatorname{AGE}$ formation $(25,26)$. In this context, recent studies in mononuclear blood cells have shown that a 2-hour period of hyperglycemia is sufficient to form intracellular AGEs, in particular, CML adducts, and to activate

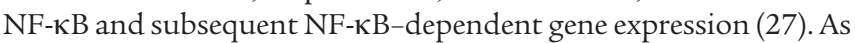
RAGE itself is subject to regulation by NF- $\mathrm{\kappa B}$ (28), upregulation of RAGE also occurs in an environment rich in RAGE ligands (29). Since the blood-nerve barrier displays increased permeability to glycated species (30), AGE-modified adducts, whether formed in the periphery or within the nervous system, have relatively easy access to the vasculature (such as the vasa nervorum) and neurons, potentially causing vascular and neuronal dysfunction, respectively. These considerations prompted us to study the impact of 


\section{Table 1}

Clinical and metabolic characteristics of the patients studied

\begin{tabular}{|c|c|c|c|}
\hline & $\begin{array}{l}\text { Control group } \\
\qquad(n=8)\end{array}$ & $\begin{array}{l}\text { Diabetes group } \\
\qquad(n=10)\end{array}$ & $\begin{array}{c}P \\
\text { value }\end{array}$ \\
\hline Type 1 diabetes & & 2 & \\
\hline Type 2 diabetes & & 8 & \\
\hline Healthy controls & 2 & & \\
\hline CMT-I & 4 & & \\
\hline CMT-II & 2 & & \\
\hline Age & $58.5 \pm 15.8$ & $56.25 \pm 9.72$ & 0.391 \\
\hline Diabetes duration & & $16.2 \pm 13.2$ & \\
\hline Retinopathy & & 6 & \\
\hline Nephropathy & & 4 & \\
\hline Peripheral arterial occlusive & disease & 5 & \\
\hline Foot ulcers or gangrene & & 5 & \\
\hline Arterial hypertension & & 5 & \\
\hline Coronary heart disease & & 4 & \\
\hline $\mathrm{HbA}_{1 \mathrm{c}}(\%)$ & ND & $7.9 \pm 1.22$ & \\
\hline Blood glucose (mg/dl) & $96.25 \pm 16.42$ & $175.5 \pm 57.6$ & 0.0017 \\
\hline Triglycerides (mg/dl) & $129.57 \pm 71.1$ & $183.7 \pm 71.18$ & 0.278 \\
\hline Cholesterol (mg/dl) & $233.57 \pm 68.29$ & $182.2 \pm 42.5$ & 0.074 \\
\hline Crea (mg/dl) & $0.725 \pm 0.12$ & $0.855 \pm 0.219$ & 0.157 \\
\hline Urea (mg/dl) & $11.5 \pm 2.81$ & $26.5 \pm 14.97$ & 0.031 \\
\hline Uric acid (mg/dl) & $5.02 \pm 1.16$ & $5.31 \pm 1.51$ & 0.743 \\
\hline Leukocytes/ul & $5,711 \pm 1,084$ & $10,350 \pm 3,741$ & 0.0038 \\
\hline \multicolumn{4}{|l|}{ Major symptoms } \\
\hline Pain/Painful paresthesia & $1 / 8$ & $3 / 10^{A}$ & \\
\hline Paresthesia/Dysesthesia & $3 / 8^{A}$ & $4 / 10^{A}$ & \\
\hline Numbness & $2 / 8^{A}$ & $6 / 10,{ }^{A} 1 / 10^{B}$ & \\
\hline Weakness & $6 / 8^{A}$ & $4 / 10^{A}$ & \\
\hline \multicolumn{4}{|l|}{ Neurologic findings } \\
\hline Impaired muscle strength & $6 / 8^{A}$ & $6 / 10^{A}$ & \\
\hline $\begin{array}{l}\text { Diminished or absent } \\
\text { ankle reflexes }\end{array}$ & $6 / 8$ & $9 / 10$ & \\
\hline $\begin{array}{l}\text { Diminished vibration } \\
\text { perception }\end{array}$ & $6 / 8^{A}$ & $10 / 10^{A}$ & \\
\hline $\begin{array}{l}\text { Diminished temperature } \\
\text { perception }\end{array}$ & $6 / 8^{A}$ & $8 / 10^{A}$ & \\
\hline Hypesthesia & $6 / 8^{A}$ & $10 / 10^{A}$ & \\
\hline Hypalgesia & $6 / 8^{A}$ & $10 / 10^{A}$ & \\
\hline
\end{tabular}

ALower limb; Bupper limb. $\mathrm{HbA}_{1 \mathrm{c}}$, glycated hemoglobin; ND, not determined. Statistically significant values are indicated in bold.

the RAGE-mediated activation of NF-אB on neuronal dysfunction in human sural nerve biopsies and animal models of diabetes in which the RAGE gene was deleted (31).

\section{Results}

Localization and colocalization of CML, RAGE, NF-кBP65, and IL-6 in sural nerve biopsies of patients with diabetes mellitus. As a first step in defining the possible relevance of AGE-RAGE interaction for activation of NF- $\kappa \mathrm{B}$, expression of NF- $\kappa \mathrm{B}-$ regulated cytokines (such as IL-6), and diabetic neuropathy, we performed immunohistochemical studies using patient-derived peripheral nerve samples. Sural nerve biopsies from patients with diabetic neuropathy (types 1 and $2 ; n=10$; Table 1 ) and Charcot-MarieTooth disease (CMT) (types I and II; $n=6$; Table 1) along with samples from healthy controls without apparent neuromuscular disease $(n=2)$ were studied to localize CML, RAGE, activated
NF-кBp65, and IL-6 antigens. For ethical reasons, biopsies from diabetic patients without neuropathy were not at disposal.

Only sural nerves from patients with diabetes displayed increased immunoreactivity for CML and RAGE epitopes in a distribution overlapping that observed for activated NF-кB and IL-6 (Figure 1A). Immunostaining for a representative biopsy from a patient with diabetes (a 51-year-old woman with type 1 diabetes; Figure 1A) illustrates these findings; prominent colocalization of these epitopes is observed in epineurial vessels, the perineurium, and endoneurial vessels (Figure 1, A and B), consistent with significant upregulation of the AGE-RAGE-NF- $\mathrm{B}$ pathway in these compartments of peripheral nerves in diabetes (Figure $1 \mathrm{~B}$, gray bars).

In contrast, biopsies from the control group, which included patients with CMT and individuals without any neuromuscular disease, failed to demonstrate coexpression of all 4 antigens (Figure $1 \mathrm{~B}$, black bars), although, occasionally, weak staining for one or another epitope was observed (Figure 1B, black bars). Remarkably, single Schwann cells expressed RAGE in 10 of 10 diabetic patients and in 4 of 8 patients of the control group but did not display CML, activated NF- $\kappa$ B, or IL-6 (data not shown). S100/calgranulins are other important RAGE ligands known to play a pivotal role in neuronal pathology (32). S100A8/A9 was expressed only in single epineurial vessels in 8 of 10 diabetic patients and in 4 of 8 control biopsies with no significant difference in the staining intensities (Figure 1C), whereas S100B was found neither in patients nor in control biopsies (data not shown). Colocalization of S100A8/A9 and RAGE was only detected in 2 of 10 patients with diabetes.

Taken together, these findings support our hypothesis that the AGE-RAGE-NF-KB pathway in peripheral nerves may be activated in patients with diabetic neuropathy. The etiology of diabetic neuropathy is considered to have a large vascular component. Since the biopsies studied were mainly taken from patients with end-stage vascular disease or to exclude vasculitis, we could not exclude confounding effects of individual inflammatory status or micro- and macrovascular disease on neuronal homeostasis. To further prove our hypothesis, we therefore studied the AGE-RAGE-NF-кB axis in well-defined animal models for experimental diabetic neuropathy.

Diabetes-dependent activation of $\mathrm{NF}-\kappa \mathrm{Bp} 50 / \mathrm{p} 65$ in peripheral nerves. Streptozotocin (STZ) was used to induce diabetes in 8-week-old transgenic mice in which expression of a $\beta$-globin transgene was under control of an NF-кB-dependent promoter (33). Under physiological conditions, constitutive expression of the transgene in these mice is restricted to lymphoid tissues, though activation of the p50/p 65 heterodimer confers inducible transgene expression in a range of cell types $(24,33)$. Induction of $\beta$-globin in sciatic nerves was monitored by semiquantitative RT-PCR, and expression of $\beta$-globin transcripts was normalized to the level of $\beta$-actin mRNA in each sample. Sciatic nerves from nondiabetic control mice demonstrated low or undetectable levels of $\beta$-globin transcripts (Figure $2 \mathrm{~A}$, lanes 1-3). In contrast, sciatic nerves from diabetic mice (average blood glucose $>400 \mathrm{mg} / \mathrm{dl}$ for 6 weeks) showed approximately 20 -fold induction of $\beta$-globin transcripts (Figure 2A, lanes 4-7; $P=0.024)$. Insulin treatment of diabetic mice, resulting in normalization of blood glucose levels (below $200 \mathrm{mg} / \mathrm{dl}$ ), reduced $\beta$-globin transcription in sciatic nerves (Figure 2B, lane 2).

To evaluate whether the AGE-RAGE-NF- $\mathrm{BB}$ axis contributes to hyperglycemia-induced $\beta$-globin gene expression observed in peripheral nerves of diabetic mice, several lines of investigation were undertaken. First, $\beta$-globin transgenic mice with overt STZ-induced diabetes (average blood glucose $>400 \mathrm{mg} / \mathrm{dl}$ for 3 months) received 
A
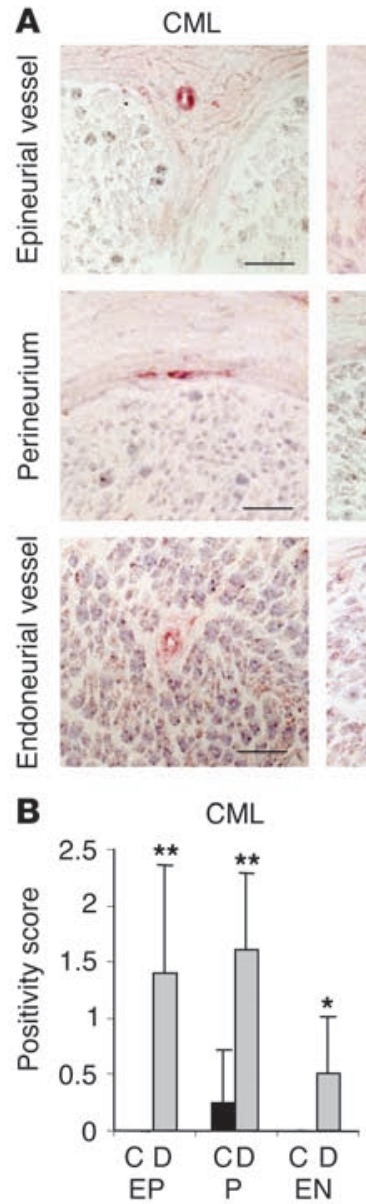

RAGE
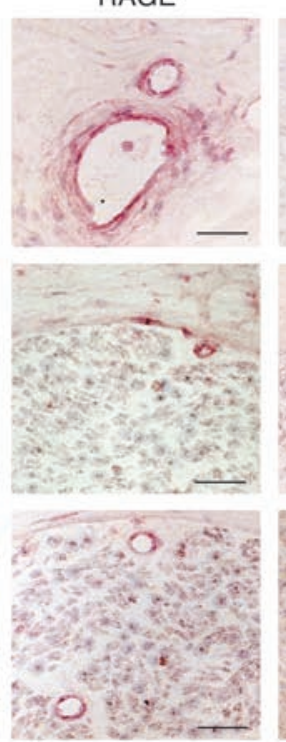

NF-кBp65
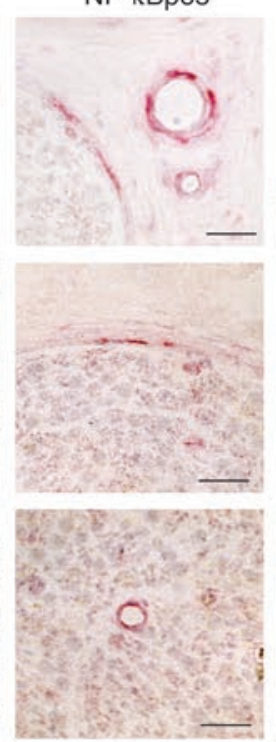

IL-6
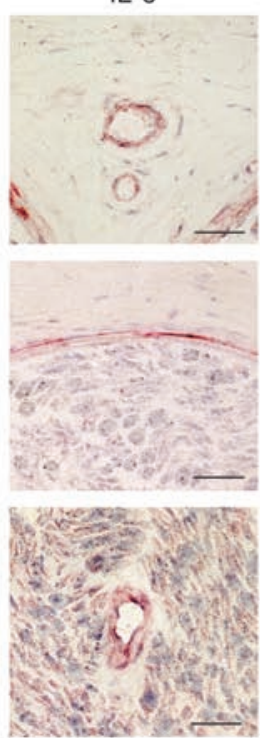
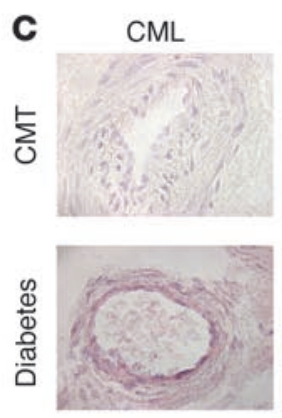

$\mathrm{S} 100 \mathrm{~A} 8 / 9$
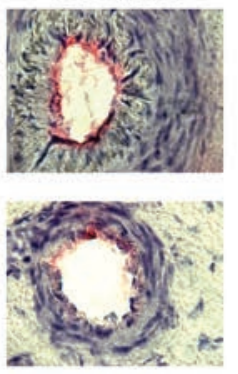
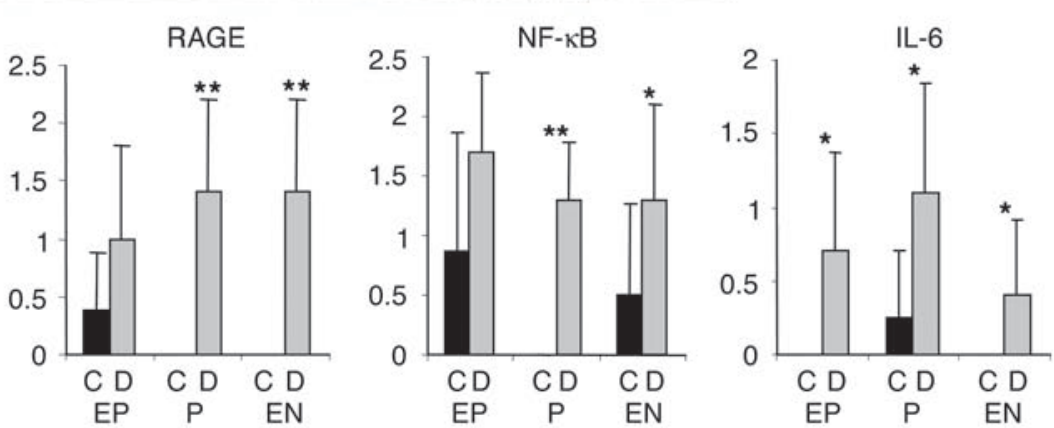

- Control

口Diabetes

\section{Figure 1}

Localization of CML, RAGE, activated NF-KBp65, and IL-6 antigens in sural nerve biopsies from patients with diabetes mellitus. (A) Representative immunohistochemical staining of a sural nerve biopsy from a 51-year-old female patient with type 1 diabetes mellitus: CML (first column), RAGE (second column), activated NF-KBp65 (third column), and IL-6 antigen (fourth column) in epineurial vessels (top), perineurium (middle), and endoneurial vessels (bottom). Positivity for the respective antigen is indicated by intense red staining. The faint blue background color is due to counterstaining with hemalaun, indicating the integrity of the tissue investigated. Scale bars: $100 \mu \mathrm{m}$. (B) Quantification of staining intensities of epineurial vessels $(E P)$, perineurium $(P)$, and endoneurial vessels $(E N)$ in nondiabetic (black bars, $n=8)$ and diabetic (gray bars, $n=10)$ patients. Data are means \pm SD; single asterisks denote $P$ values less than 0.05 , which we considered to be statistically significant; double asterisks denote $P$ values less than 0.005 , which we considered to be highly statistically significant. (C) Comparison of the staining intensity for the RAGE ligand CML (left) and the RAGE ligand S100A8/A9 (right) in sural nerve biopsies from a 56-year-old male patient with CMT-I (top) and a 66-year-old male patient with type 2 diabetes (bottom). Representative epineurial vessels are shown. Magnification, $\times 400$.

soluble RAGE (sRAGE; $100 \mu \mathrm{g} / \mathrm{mouse} /$ day i.p. for 3 weeks), a truncated form of the receptor comprising the extracellular domain of RAGE (sRAGE functions as a decoy to bind ligands and prevents their interaction with the cell surface receptor [ref. 29]). Treatment with sRAGE for 3 weeks completely inhibited NF-кB-dependent $\beta$-globin transcription in diabetic mice (Figure $2 \mathrm{C}$, lane 3 ), thus implying at least a partial involvement of RAGE. Next, we performed experiments using exogenous AGEs. Healthy 8-week-old $\beta$-globin transgenic mice received a single dose of AGE-modified albumin (AGE-albumin) or native albumin (1 $\mathrm{mg}$ in each case; $500 \mu$ g i.v., $500 \mu$ g i.p.) (24). Sciatic nerves were harvested 6 days later and subjected to RT-PCR for detection of $\beta$-globin transcription. As previously described, this AGE concentration is in the range of AGEserum levels determined in diabetic patients and in experimental diabetes (24). Because of degradation and cellular and urinary AGE clearance, AGE concentrations in the mice 6 days after injection were even below AGE-serum levels found in diabetic patients with good glycemic control. Under these experimental conditions, prominent $\beta$-globin transcription was observed in AGE-albumin-treated mice (Figure 2D, top, lane 2). The level of $\beta$-globin transcripts was strongly reduced when mice received either sRAGE $(25 \mu \mathrm{g} /$ mouse i.v.; Figure 2D, top, lane 3$)$ or neutralizing anti-RAGE IgG $(40 \mu \mathrm{g} /$ mouse i.v.) (24) (Figure 2D, top, lane 4). The level of $\beta$-globin transcripts was undetectable in mice infused with native albumin (Figure 2D, top, lane 1) and in untreated control mice (data not shown). An important feature of RAGE-mediated NF- $\kappa \mathrm{B}$ activation is that it upregulates NF-кBp65 expression, thereby promoting sustained activation of this transcription factor in an environment rich in RAGE ligands (24). An increase in the level of NF- $\mathrm{kBp} 65$ transcripts was observed in sciatic nerves from mice receiving AGE-albumin (Figure 2D, middle, lane 2). Elevated NF-кBp65 transcription in mice treated with AGE-albumin was prevented by simultaneous 
A

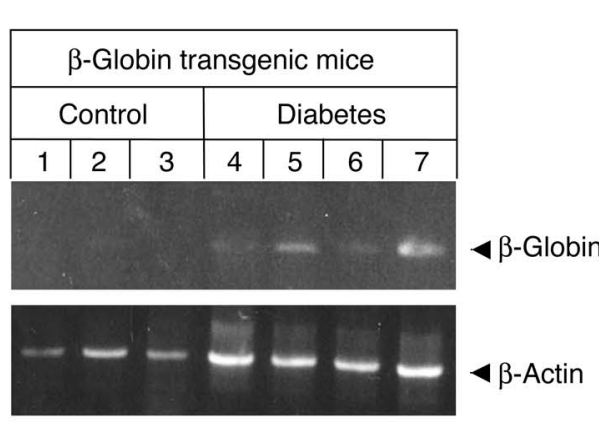

D

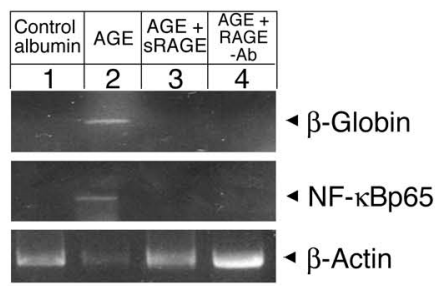

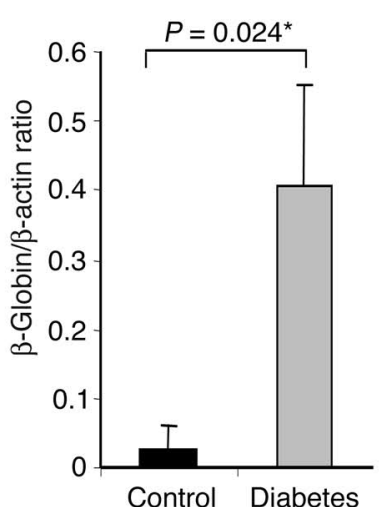

E

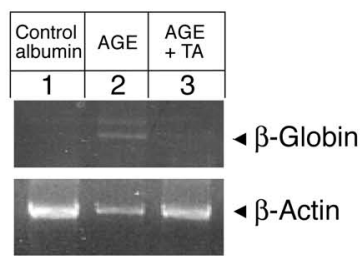

B

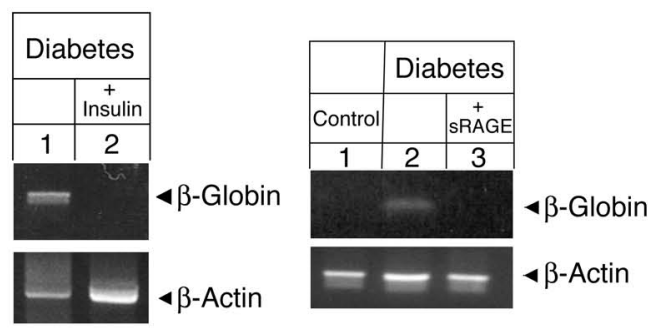

F

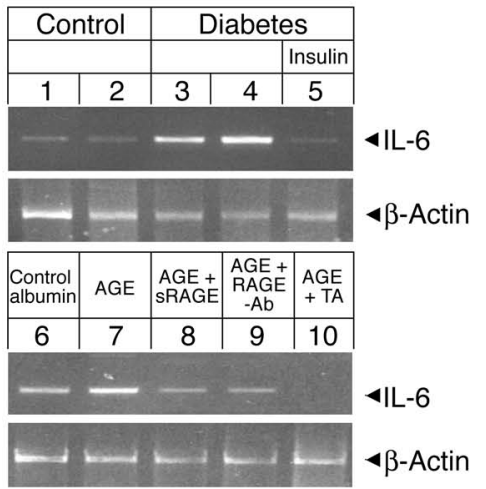

\section{Figure 2}

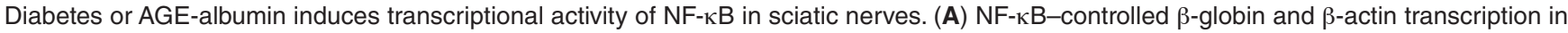
sciatic nerves of healthy control mice (lanes 1-3) and diabetic mice (lanes 4-7) 6 weeks after induction of diabetes; bar graphs summarize the semiquantitative results ( $\beta$-globin/ $\beta$-actin ratio) obtained in all mice studied (black bar, control; gray bar, diabetes). The mean \pm SD is reported; ${ }^{*} P<0.05$. The number of mice studied was 4 for controls, 5 for diabetes. (B) $\beta$-Globin and $\beta$-actin transcription in sciatic nerves of diabetic mice with bad glycemic control (lane 1) and good glycemic control due to intensified insulin treatment (lane 2); $n=2$ for each group. (C) $\beta$-Globin and $\beta$-actin transcription in sciatic nerves of healthy controls (lane 1) compared with mice that had had diabetes for 3 months, without (lane 2 ) and with sRAGE treatment (lane 3); $n=3$ for each group. ( $\mathbf{D}$ and $\mathbf{E}) \beta$-Globin, NF-кBp65, and $\beta$-actin transcription in sciatic nerves of mice treated with native albumin (lane 1), AGE-albumin alone (lane 2), or AGE-albumin in the presence of sRAGE (D, lane 3), anti-RAGE IgG (RAGE-Ab; D, lane 4), or the antioxidant thioctic acid (TA; E, lane 3); $n=3$ for each group. (F) IL-6 transcription in sciatic nerves studied in A-E from healthy (lanes 1 and 2) and diabetic (lanes 3-5) mice with bad (lanes 3 and 4) and good (lane 5) glycemic control and mice treated with native albumin (lane 6), AGE-albumin alone (lane 7), or AGE-albumin in the presence of sRAGE (lane 8), anti-RAGE IgG (lane 9), or thioctic acid (lane 10).

treatment with sRAGE or anti-RAGE IgGs (Figure 2D, middle, lanes 3 and 4). In view of the known association of RAGE-driven NF- $\kappa B$ activation with oxidant stress, we tested the effect of the antioxidant thioctic (lipoic) acid, previously shown to reduce AGE-mediated NF- $\mathrm{B}$ activation in vitro (19) and in vivo (20). Thioctic acid prevented upregulation of $\beta$-globin transcripts in sciatic nerves from mice treated with AGE-albumin (Figure 2E, top, lane 3).

The proinflammatory cytokine IL- 6 is an NF- $\mathrm{BB}-$ regulated gene (34) that has recently been shown to attenuate nociception in neuropathic rats by inhibition of spinal neuronal responses and thereby to modulate neuronal function (35). In addition, colocalization of IL- 6 with CML adducts as well as RAGE and NF-кBp65 is evident in epineurial and endoneurial vessels and in the perineurium of sural nerve biopsies from patients with diabetes (Figure 1). To assess whether an increase in IL-6 expression is also evident in peripheral nerves in experimental diabetic neuropathy, IL-6-specific RT-PCR was performed in sciatic nerves of diabetic mice and mice treated with AGE-albumin (Figure 2F). After 6 weeks of hyperglycemia, the level of IL- 6 transcripts increased (Fig- ure $2 \mathrm{~F}$, top, lanes 3 and 4). This increase in IL- 6 mRNA in diabetic mice was prevented by insulin therapy (Figure $2 \mathrm{~F}$, top, lane 5 ). In a different experimental system, mice treated with AGE-albumin also showed an increase in IL-6 transcripts (Figure 2F, bottom, lane 7 ), which was clearly attenuated (though not completely eliminated) by administration of sRAGE (Figure 2F, bottom, lane 8) or anti-RAGE IgG (Figure 2F, bottom, lane 9). When mice exposed to AGE-albumin were treated with thioctic acid, complete inhibition of IL-6 transcripts was observed (Figure 2F, bottom, lane 10). These data indicate that redox-sensitive mechanisms are essential for AGE-induced NF- $\kappa \mathrm{B}$ activation and NF- $\kappa \mathrm{B}-$ dependent gene expression such as IL- 6 expression. Furthermore, the RAGE-mediated pathway plays an important, though not exclusive, role.

Activation of NF- $\kappa B$ in dorsal root ganglia: effect of $R A G E$ expression. To directly assess whether RAGE participated in hyperglycemia and/ or AGE-dependent NF- $\kappa B$ activation, experiments were performed using dorsal root ganglia (DRG) from homozygous RAGE-null $\left(\mathrm{RAGE}^{-/-}\right)$mice $(31,36)$ and strain-matched (SVEV129×C57BL/6) controls (WT). Cultured DRG from 6-month-old WT and RAGE-/- 
A
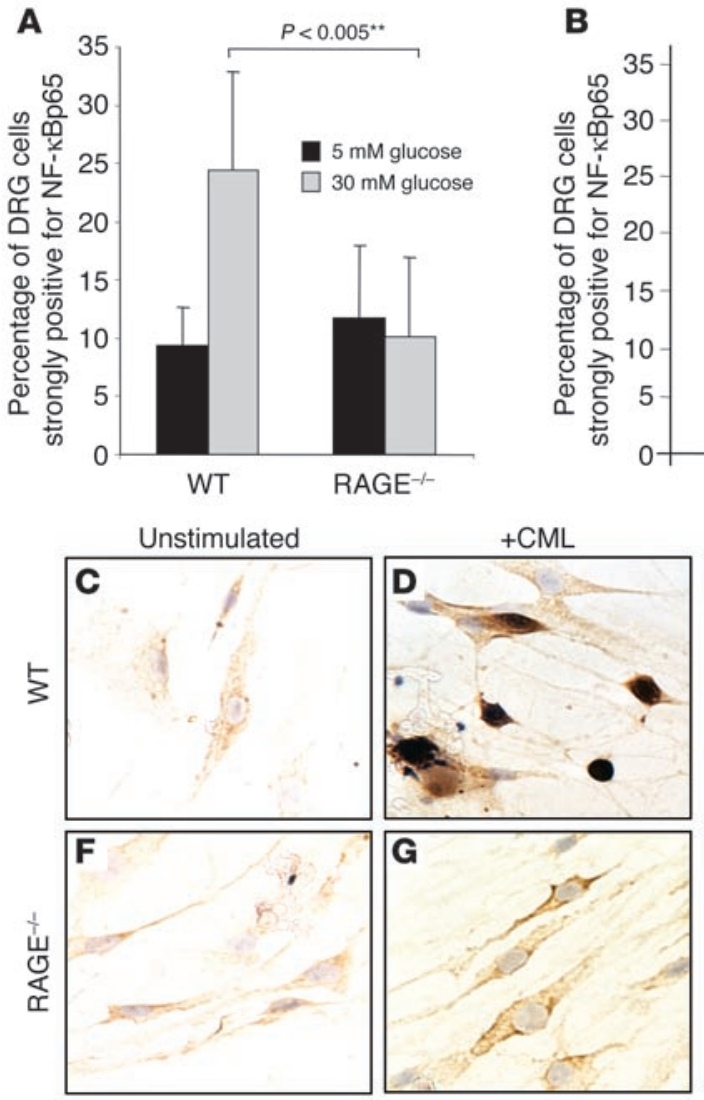

B

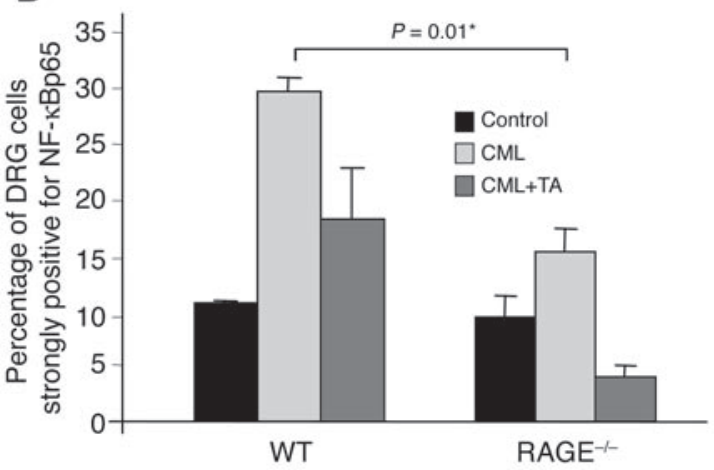

$+\mathrm{CML}+\mathrm{TA}$
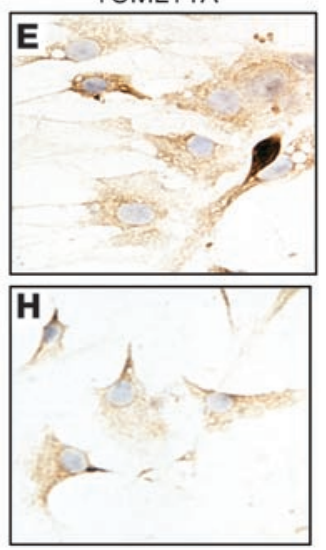

Figure 3

DRG from RAGE-/- mice exhibit reduced NF-kBp65 inducibility in response to hyperglycemia or CMLalbumin. (A and B) DRG from WT and RAGE-/- mice were (A) cultivated for 5 days in $5 \mathrm{mM}$ glucose or 30 $\mathrm{mM}$ glucose or (B) cultivated for 5 days without further treatment or with $\mathrm{CML}(800 \mathrm{nM})$ in the absence or presence of thioctic acid (TA), before immunocytochemistry for activated NF-KBp65 was performed. Bar graphs summarize the number of cells strongly positive for activated NF-kBp65. The mean \pm SD is reported; ${ }^{*} P<0.05 ;{ }^{* *} P<0.005$. (C-H) Immunocytochemistry for activated NF-KBp65 antigen in DRG isolated from WT $(\mathbf{C}-\mathbf{E})$ or RAGE ${ }^{-/}(\mathbf{F}-\mathbf{H})$ mice, which were untreated $(\mathbf{C}$ and $\mathbf{F})$ or had been stimulated with $\mathrm{CML}$ in the absence $(\mathbf{D}$ and $\mathbf{G})$ or presence $(\mathbf{E}$ and $\mathbf{H})$ of thioctic acid. Positivity for activated NF-kBp65 is indicated by a dark brown color. The experiment was repeated 3 times with identical results. One representative staining is shown. Magnification, $\times 400$.

mice were cultured in either $5 \mathrm{mM}$ or $30 \mathrm{mM}$ glucose for 5 days and then subjected to immunostaining with an antibody selectively recognizing activated NF- $\mathrm{\kappa Bp} 65$. While DRG from both WT and $\mathrm{RAGE}^{-/-}$mice cultured in $5 \mathrm{mM}$ glucose only occasionally stained strongly positive for activated NF-kBp65 (Figure 3A), increasing the glucose concentration to $30 \mathrm{mM}$ resulted in a 2.5 -fold increase in WT DRG strongly positive for activated NF-kB65. In contrast, no glucose-dependent increase in activated NF- $\mathrm{\kappa Bp} 65$ was observed in DRG isolated from $\mathrm{RAGE}^{-/-}$mice (Figure 3A). A comparable activation pattern was observed when DRG were incubated with CMLmodified albumin (CML-albumin) (Figure 3B) for 5 days. CMLalbumin prepared in vitro was chosen for these experiments, since (a) CML colocalized with RAGE in diabetic sural nerve biopsies, (b) CML was the predominant AGE modification in the AGE-albumin prepared in vitro that was used above (Figure 2), and (c) chemically produced CML-albumin provides a more defined ligand for RAGE (37) than the crude AGE-albumin. DRG were left untreated (Figure 3, B, C, and F), exposed to native albumin (data not shown), or incubated with $800 \mathrm{nM} \mathrm{CML}$ alone (Figure 3, B, D, and G) or in the presence of $100 \mu \mathrm{M}$ thioctic acid (Figure 3, B, E and H). An immunohistochemical signal for activated NF-KBp65 was observed at a low base line in unstimulated cultures (Figure 3, B, C, and F) and DRG exposed to native albumin (data not shown), independent of cell origin (WT or RAGE-/- mice). After exposure to CML-albumin, DRG obtained from WT mice exhibited prominent activation of NF-kB ( $P=0.006$; Figure $3, \mathrm{~B}$ and $D)$, while expression of the activated NF-kBp65 epitope increased minimally, without statistical significance, in DRG extracted from $\mathrm{RAGE}^{-/}$mice (Figure 3, B and G). Cultures exposed to thioctic acid along with CML-albumin also showed reduced expression of activated NF-кBp65 (Figure $3, \mathrm{~B}, \mathrm{E}$, and $\mathrm{H}$ ). It is important to note that thioctic acid reduced the low level of NF-KB activation beyond base line in $\mathrm{RAGE}^{-/-} \mathrm{DRG}$, consistent with its ability to suppress both RAGE-dependent and RAGE-independent pathways leading to NF-KB activation.

RAGE-dependent NF- $\mathrm{K} B$ activation and induction of IL-6 transcripts in diabetes. WT and $\mathrm{RAGE}^{-/-}$mice were rendered diabetic with STZ. Six months later, NF-кB activation and IL-6 expression were assessed in the sciatic nerves. Electrophoretic mobility shift assay (EMSA) of nuclear extracts from sciatic nerves was examined for NF-KB binding activity (Figure 4A). The intensity of the gel shift band increased 5 -fold in diabetic WT mice $(P=0.0004)$. In contrast, there was no increase in intensity of the gel shift band when nondiabetic and diabetic $\mathrm{RAGE}^{-/-}$mice were compared (Figure 4A). A plot of the level of NF-кB binding activity against the blood glucose over the 6-month experimental period indicated a significant positive correlation in WT mice $(P=0.0001$; Pearson coefficient $=0.867 ; r^{2}=0.745$; Figure $4 \mathrm{~A}$, left), but not in RAGE $-/-$ mice $\left(P=0.7329\right.$; Pearson coefficient $=-0.094 ; r^{2}=-0.0089$; Figure $4 \mathrm{~A}$, right). These data indicate a central role for RAGE in diabetesdependent NF-kB activation in peripheral nerve.

We next sought to determine whether expression of IL-6 transcripts in diabetic peripheral nerve would be affected by RAGE. RT-PCR analysis was performed on peripheral nerve using primers for IL-6 in a semiquantitative approach (as in Figure 2). Euglycemic WT mice demonstrated very low or undetectable levels of IL- 6 transcripts, whereas WT mice studied after 6 months of diabetes displayed an approximately 2.7-fold increase in IL-6 
A

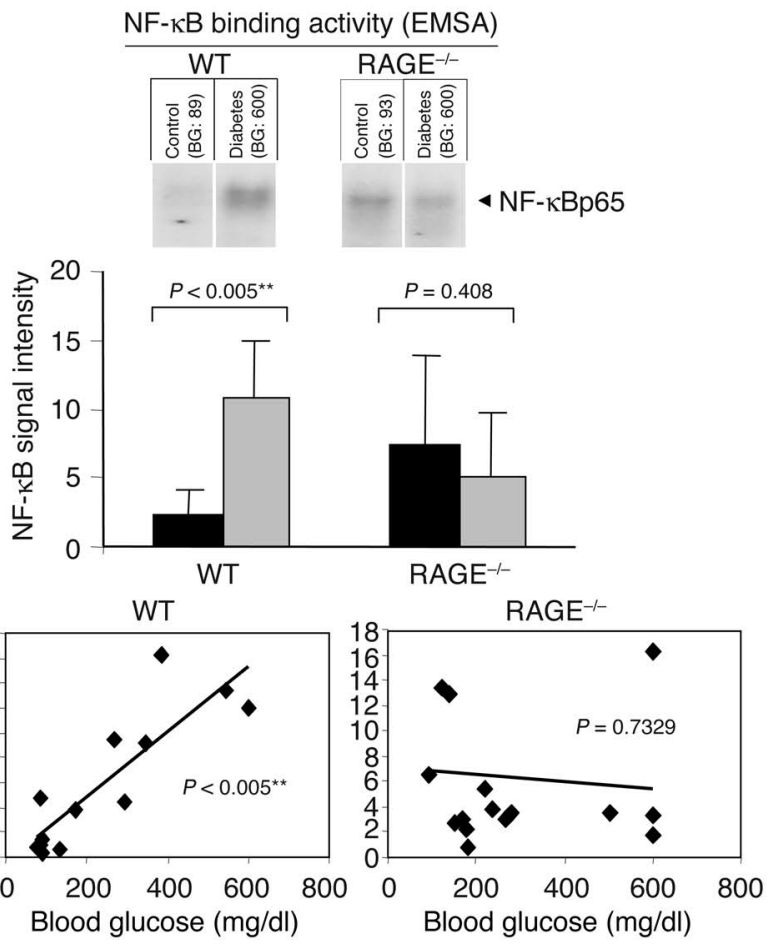

B

IL-6 transcription (RT-PCR)
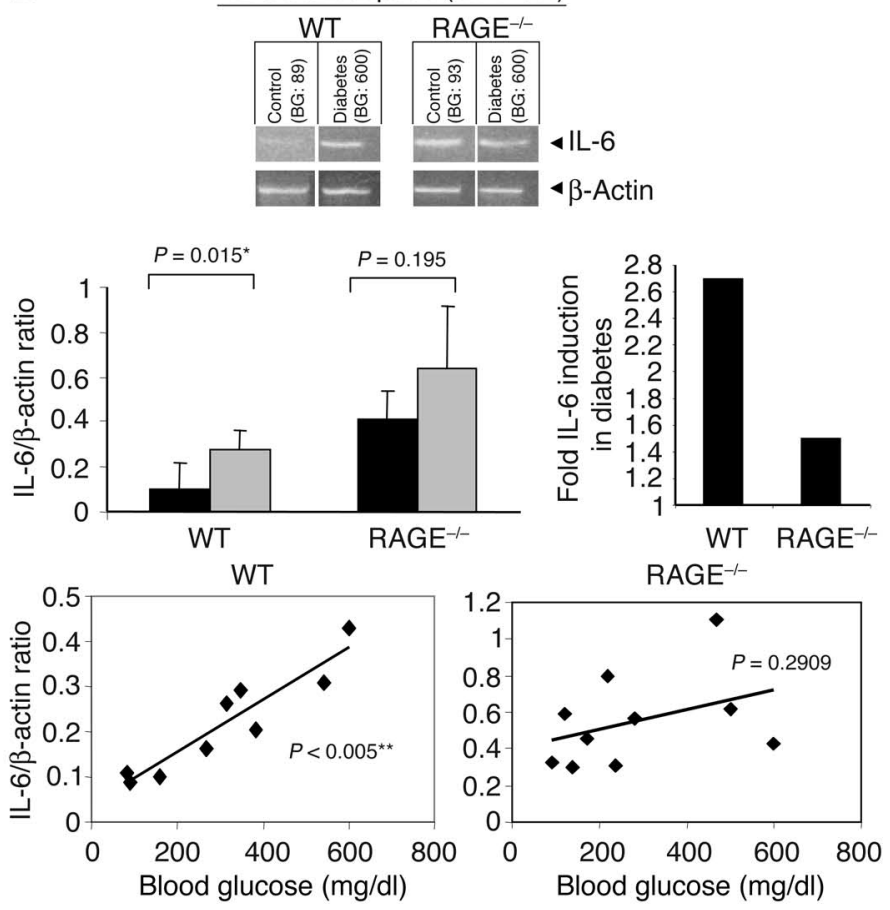

Figure 4

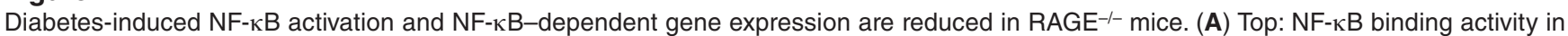
sciatic nerves of healthy and diabetic WT and $\mathrm{RAGE}^{-/-}$mice 6 months after diabetes manifestation, measured by EMSA. The arrow indicates the NF-KB complex. BG, blood glucose (mg/dl, as indicated). Middle: Signals obtained in all mice were quantified by densitometry as summarized in the bar graph (black bars, control; gray bars, diabetes). The mean $\pm \mathrm{SD}$ is reported. Bottom: Correlation of NF- $\mathrm{KB}$ signal intensity with the blood glucose levels of each mouse maintained throughout the experiment. The number of mice studied was 7 for WT controls, 6 for WT mice with diabetes, 8 for RAGE ${ }^{-/}$controls, and 8 for RAGE ${ }^{-/-}$mice with diabetes. ${ }^{* \star} P<0.005$. (B) Top: NF-אB-dependent IL-6 transcription in sciatic nerves from healthy and diabetic WT and RAGE ${ }^{--}$mice, determined by semiquantitative RT-PCR. Middle: Bar graphs summarize the IL-6/ $\beta$-actin ratio obtained in all mice (black bars, control; gray bars, diabetes) (left graph) and the extent of IL-6 induction in diabetic mice (right graph). The mean \pm SD is reported. Bottom: Correlation of the IL-6 mRNA/ $\beta$-actin ratio with the blood glucose level of each individual mouse. The number of mice investigated by RT-PCR was 3 for WT controls, 6 for WT mice with diabetes, 4 for RAGE ${ }^{-/}$controls, and 6 for RAGE ${ }^{-/-}$mice with diabetes. ${ }^{*} P<0.05 ;{ }^{*} P<0.005$.

mRNA $(P=0.015$; Figure 4B). The situation was quite different in $\mathrm{RAGE}^{-/-}$mice; there was a small increase (approximately 1.5 -fold) in IL-6 transcripts, but this did not achieve statistical significance $(P=0.195$; Figure 4B). It should be noted that baseline levels of IL-6 transcripts were higher in $\mathrm{RAGE}^{-/-}$mice than in WT mice (Figure $4 \mathrm{~B})$, which is analogous to what was observed for NF- $\mathrm{KB}$ activation (Figure 4A). This slightly elevated NF- $\mathrm{B}$ activation is consistent with previous observations in other tissues of $\mathrm{RAGE}^{-/}$mice (36). Studies are currently under way to identify the mechanism underlying the mild proinflammatory phenotype of $\mathrm{RAGE}^{-/-}$mice. The impact of hyperglycemia was shown by plotting of the IL-6/ $\beta$-actin ratio against blood glucose levels that were maintained throughout the experiment (Figure 4B, bottom panel). In WT mice, the level of hyperglycemia strongly correlated with expression of IL- 6 transcripts $(P=0.0098$; Pearson coefficient $=0.751$; $r^{2}=0.8704$; Figure 4B, bottom left). This was not the case in $\mathrm{RAGE}^{-/}$ mice. There was no significant correlation between the extent of hyperglycemia and the level of IL- 6 transcripts $(P=0.2909$; Pearson coefficient $=0.386 ; r^{2}=0.1493$; Figure 4B, bottom right).

Diabetes-induced loss of pain perception: effect of RAGE expression. To further determine the contribution of RAGE to diabetes-induced loss of pain perception, indicative of long-standing diabetic neuropathy, mice were tested for thermonociception using the hot-plate test at $50-55^{\circ} \mathrm{C}(38,39)$. When healthy $\beta$-globin transgenic mice (see also Figure $2 \mathrm{C}$ ) were compared with littermates that had had STZinduced diabetes for 3 months, pain perception in diabetic mice was significantly reduced (Figure 5), and lifting, licking, and jump latency at $55^{\circ} \mathrm{C}$ declined from $7.3 \pm 2.1$ seconds to $11.4 \pm 4.6$ seconds $(P=0.0005)$. Treatment with sRAGE $(100 \mu \mathrm{g} /$ mouse/day for 3 weeks $)$ completely restored pain perception and corrected the latency time to $7.1 \pm 1.9$ seconds $(P=0.003$; Figure 5$)$.

These data indicated that RAGE contributes to the diabetes-mediated increase in nociceptive threshold. Thus, we asked whether RAGE deficiency protects from diabetes-associated loss of cutaneous nerve fibers. When footpad sections of healthy and diabetic mice were stained with the neuronal marker protein gene product PGP9.5 (40), however, diabetic $\mathrm{RAGE}^{-/}$mice displayed reduced cutaneous innervation in footpad skin regions to the same extent that diabetic WT mice did (Figure 6A). No changes in foot skin thickness could be detected morphologically (data not shown). In addition, no significant differences in motor and sensory nerve conduction velocities (measured under temperaturecontrolled conditions) were observed between healthy and diabetic nor between WT and $\mathrm{RAGE}^{-/-}$mice (data not shown). 


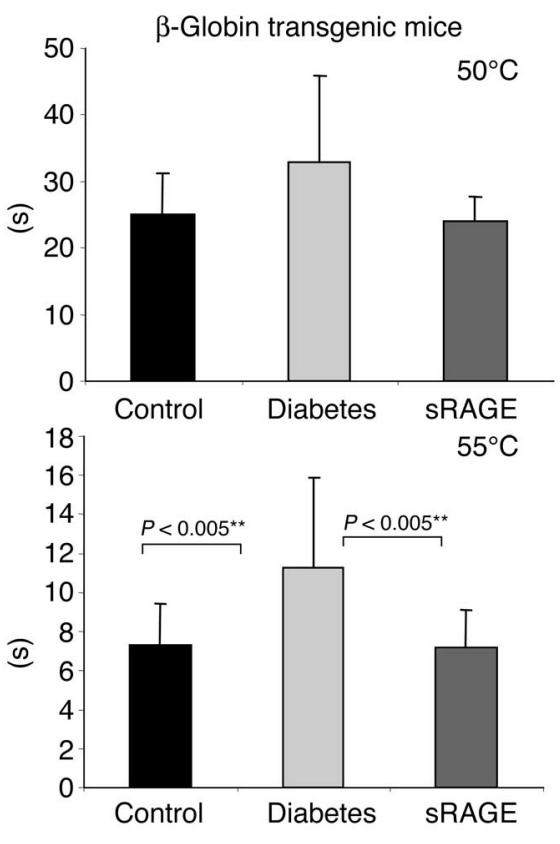

However, when the nociceptive threshold at $50^{\circ} \mathrm{C}$ was determined in WT and $\mathrm{RAGE}^{-/-}$mice, diabetes-induced loss of pain perception was largely prevented in diabetic $\mathrm{RAGE}^{-/}$mice (Figure 6B). While the basal pain response in the hot-plate test did not differ significantly between WT and RAGE-/- mice (Figure 6B, black bars), nociceptive threshold in WT mice with STZ-induced diabetes was significantly increased after 6 months (Figure 6B). Importantly, deletion of the RAGE gene afforded protection from the increased nociceptive threshold caused by diabetes, with the time recorded until mice showed signs of discomfort being significantly longer in diabetic WT mice (45.02 \pm 10 seconds) than in diabetic $\mathrm{RAGE}^{-/-}$mice (37.52 \pm 16 seconds; $P=0.007$; Figure $6 \mathrm{~B})$. Diabetes prolonged the mean latency by 12.6 seconds in WT mice, but only by 8.8 seconds in $\mathrm{RAGE}^{-/-}$mice $(P=0.014$; Figure 6C). These results imply that RAGE is involved in diabetic neuropathy, by mediating functional sensory deficits, but not in loss of small nerve fibers, as evidenced by the number of PGP9.5-positive cutaneous nerve fibers counted (Figure 6A).

\section{Discussion}

There are multiple potential mechanisms by which hyperglycemia results in the sustained cellular perturbation that underlies the chronic complications that contribute to morbidity and mortality in diabetes $(25,26)$. The data presented herein demonstrate a role for AGEs via the receptor RAGE in triggering events that lead to neuronal dysfunction and, ultimately, neuropathy. Previous studies have shown upregulation of RAGE and its ligands, such as AGEs and S100/calgranulins, at sites of vascular lesions in diabetes (24, 29, $41,42)$. Other studies have displayed enhanced expression of RAGE in juxtaposition to sites of deposition of amyloid- $\beta$ peptide $(A \beta)$, another ligand of RAGE, in brains of patients with Alzheimer disease (43). To our knowledge, ours is the first study showing that RAGE expression is enhanced in cells proximal to accumulated AGEs in peripheral nerves of patients with diabetes and neuropathy.

One of the salient features of RAGE-mediated cellular activation concerns its chronicity. In a previous in vitro study, we found that, in contrast to cytokine-mediated NF-KB activation, which is rela-

\section{Figure 5}

Diabetes-induced loss of pain perception is reduced in the presence of SRAGE. $\beta$-Globin transgenic mice that had had diabetes for 3 months showed significantly reduced latencies in the hot-plate assay at high $\left(55^{\circ} \mathrm{C}\right)$ but not at low $\left(50^{\circ} \mathrm{C}\right)$ temperature setting when compared with healthy controls. Three weeks' treatment of diabetic mice with sRAGE (100 $\mu \mathrm{g} / \mathrm{mouse} / \mathrm{day}$ ) completely restored pain perception. The number of mice studied was 5 for controls, 3 for diabetes, and 3 for diabetes plus SRAGE. ${ }^{* *} P<0.005$.

tively brief in duration (over hours), AGE-RAGE-induced nuclear translocation of NF-KB lasted much longer (more than 1 week) (24). In diabetes, activation of this transcription factor also appears to be sustained in clinical as well as laboratory settings (24). For the current studies with STZ-induced diabetes, NF- $\kappa \mathrm{B}$ activation in sciatic nerves was evident based on expression of a $\beta$-globin transgene driven by NF- $\mathrm{B}$ promoter elements. A key question concerns the means by which the immediate effects of hyperglycemia are converted to sustained cellular activation in peripheral nerve tissue. One potential mechanism appears to involve formation of AGEs and their interaction with cells within the nerve bearing RAGE. First, infusion of AGE-albumin into euglycemic mice led to activation of NF- $\mathrm{KB}$ and expression of an NF-אB-regulated gene, IL-6. Preventing access of this AGE ligand to cell surface RAGE, using either sRAGE or antiRAGE IgG, largely suppressed both NF- $\kappa \mathrm{B}$ activation and expression of IL- 6 transcripts in sciatic nerve. Second, exposure of DRG cells to hyperglycemia or CML-albumin (carboxymethylation of lysine represents the most abundant AGE modification identified in vivo; refs. 14, 15, 37, 41, 42) caused appearance of activated NF-кBp65 epitopes in the nucleus in diabetic WT mice, whereas the response to both stimuli was strongly blunted in $\mathrm{RAGE}^{-/}$mice. Third, diabetic WT mice demonstrated both NF-кB activation and expression of IL- 6 transcripts in sciatic nerve, both of which were attenuated in $\mathrm{RAGE}^{-/-}$mice. Taken together, these data indicate that AGE-RAGE interaction is a possible mechanism underlying sustained activation

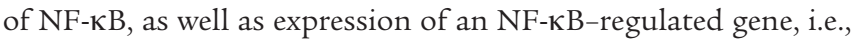
IL-6, in peripheral nerves of diabetic mice.

The central issue concerns the functional significance of RAGEmediated cellular activation for diabetic neuropathy. Our experiments evaluating the nociceptive threshold in diabetic mice bear directly on this issue. Whereas WT mice rendered diabetic displayed the expected increase in nociceptive threshold, $\mathrm{RAGE}^{-/-}$ mice showed minimal changes in their response to a noxious test stimulus (Figure 6B). Although sensory deficits evidenced by loss of pain perception were reduced in diabetic $\mathrm{RAGE}^{-/-}$mice, diabetes-induced loss of PGP9.5-positive small plantar nerves was similar to that observed in diabetic WT mice (Figure 6A). Therefore, RAGE seems to be involved in loss of function, but not in organic structural damage mediated by diabetes. Consistently, treatment of diabetic mice with sRAGE restores pain perception by correcting neuronal deficits (Figure 5). It is noteworthy that sRAGE completely restored pain perception in diabetic WT mice (Figure 5), while $\mathrm{RAGE}^{-/-}$mice were only partly protected from diabetes-induced sensory deficits. This indicates that sRAGE inhibits ligands capable of binding RAGE, but also of interacting with other binding sites that contribute to the diabetes-dependent increase in nociceptive threshold.

These observations raise multiple questions regarding mechanisms by which RAGE triggers signaling pathways that lead to neuronal dysfunction. Although RAGE is known to induce 
A
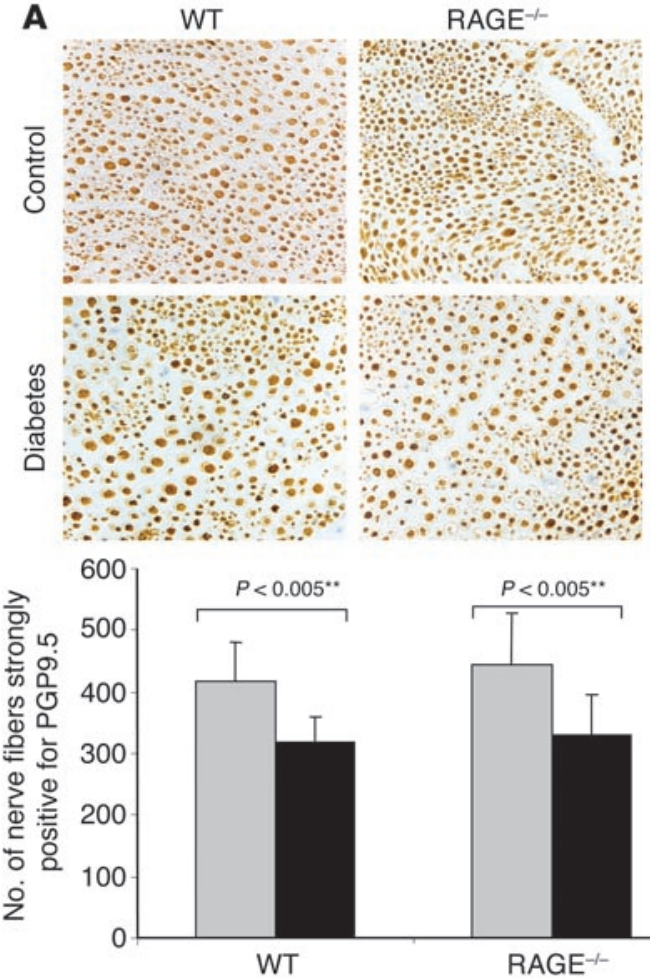

B

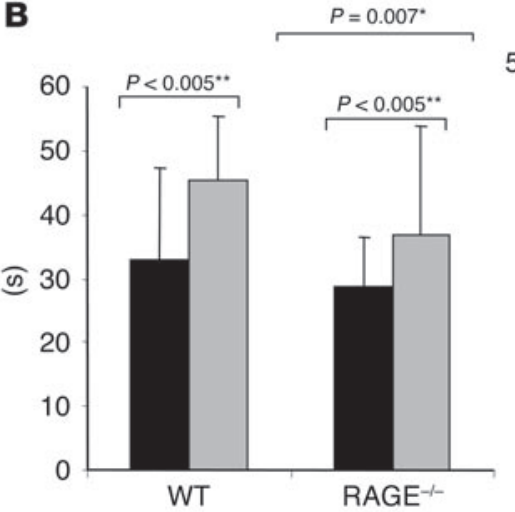

C

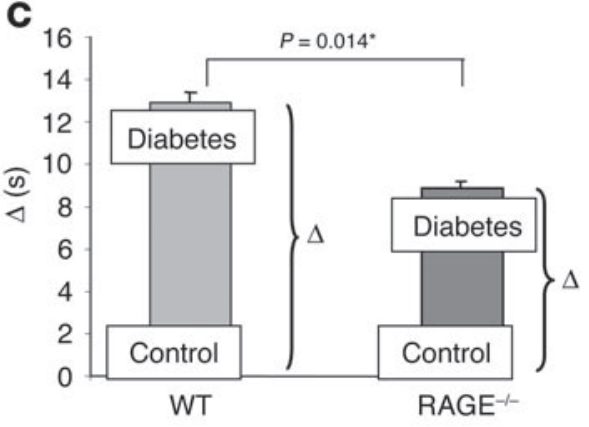

Figure 6

$\mathrm{RAGE}^{-/-}$mice are partly protected from diabetes-induced loss of pain perception, but not from diabetesinduced loss of PGP9.5-positive plantar nerves. (A) Immunohistochemical reaction of small fibers in footpad skin of WT and RAGE-- mice with the neuronal marker gene product PGP9.5. The number of mice studied was 3 for healthy controls (black bars) and 5 for diabetic mice (gray bars). At least 3 visual fields were evaluated for each mouse. The mean $\pm \mathrm{SD}$ is reported; ${ }^{* *} P<0.005$. Magnification, $\times 40$. (B) Mean hind-paw lick latency in the hot-plate assay $\left(50^{\circ} \mathrm{C}\right)$ in WT and RAGE ${ }^{-/-}$mice that were healthy (black bars) or had had diabetes for 6 months (gray bars). The number of mice studied was 6 for WT controls, 10 for WT mice with diabetes, 10 for $\mathrm{RAGE}^{-/-}$control mice, and 9 for RAGE ${ }^{-/}$mice with diabetes. The mean $\pm \mathrm{SD}$ is reported; ${ }^{*} P<0.05 ;{ }^{* *} P<0.005$. (C) Extent of diabetes-induced loss of pain perception, evidenced by the increase $(\Delta)$ in paw lick latency in WT (light gray bar) and $\mathrm{RAGE}^{-/-}$(dark gray bar) mice. The mean $\pm \mathrm{SD}$ is reported; ${ }^{*} P<0.05$.

NF- $\kappa \mathrm{B}$ activation $(19,24,28,36,41,42)$, it is not clear whether this pathway underlies RAGE-dependent neuronal dysfunction in diabetes. In this context, NF- $\mathrm{KB}$ activation in the nervous system has been shown to induce expression of genes important for the cellular response to injury and neuronal plasticity (16), such as IL-6, which is a proinflammatory gene product able to attenuate nociception (35). Thus, it is possible that the initial pulse of NF- $\kappa \mathrm{B}$ activation has cytoprotective properties in the setting of oxidant stress $(26,34,44)$. However, more sustained NF- $\kappa \mathrm{B}$ activation might have deleterious consequences for neuronal properties. Alternatively, NF- $\mathrm{B}$ activation in cells of the vessel wall of the vasa nervorum could lead to vascular dysfunction, and, subsequently, to neuronal dysfunction. An association between microangiopathy and neuropathy has long been considered $(2,6,10,45)$, and the AGE-RAGE axis could be one mechanism by which vascular changes ultimately lead to neuronal damage. This interpretation is supported by the observation that the colocalization of CML, RAGE, NF- $\mathrm{BB}$, and IL-6 was restricted to epineurial vessels, perineurium, and endoneurial vessels (Figure 1), while axons from both patients with diabetes and nondiabetic controls were negative for each of the 4 antigens. The discontinuity between sites of AGE accumulation, maze (47). Furthermore, longterm potentiation is also reduced in mice overexpressing RAGE in the context of an increased A $\beta$ load in the CNS (47). These subtle changes in neurologic function occurred in the absence of overt cell death. We believe that there are strong analogies between the situation in which transgenic mice overexpress neuronal RAGE in an A $\beta$-rich environment and the observations presented here in diabetic mice. In both cases, sustained RAGE-mediated cellular activation results in neuronal dysfunction, most likely because of perturbation of intracellular signaling pathways. The findings presented in this study unequivocally delineate a role for RAGE, since deletion of the RAGE gene caused improved neurologic function.

It is important to point out that although deletion of the RAGE gene or blockade of RAGE (with sRAGE or antibodies to the receptor) had a strong protective effect in our studies, inhibition of cellular dysfunction in diabetic mice was not complete; i.e., despite inactivation of RAGE, activation of NF- $\kappa$ B and expression of IL- 6 mRNA still occurred at a low level, and neurologic function (with respect to nociception) was not fully maintained. Moreover, RAGE deficiency did not protect from diabetes-induced loss of PGP9.5positive small fibers (Figure 6A). These data suggest that although RAGE has a substantial role in mechanisms leading to neuronal 
stress and subsequent functional sensory deficits in diabetes, it is certainly not the only factor. However, by delineating AGE-RAGE interaction as a discrete target impacting on neuronal function, the current work suggests the potential utility of therapeutic approaches focused on RAGE in neuropathy, an area where few therapeutic options are currently available.

\section{Methods}

\section{Patient characteristics}

Nerve biopsy specimens were obtained from 10 patients with diabetic neuropathy. In 5 patients, diagnostic sural nerve biopsy was performed for exclusion of vasculitis. In 5 patients who had to undergo therapeutic amputation of the lower limb because of peripheral arterial occlusive disease stage 4 , the sural nerves were taken out immediately after the amputation. Clinical characteristics and metabolic data are shown in Table 1. The diabetic neuropathy was distal symmetrical in all patients and was diagnosed according to the San Antonio criteria (48). Other causative factors for polyneuropathies, such as neoplasia, bacterial, viral, or autoimmune inflammation, endocrinopathies (other than diabetes), chronic alcohol abuse, vitamin deficiency, drug or heavy metal intoxication, and hereditary factors, were excluded by a standardized diagnostic program (49).

All patients with peripheral vascular disease (PVD) and 3 of 5 patients without PVD showed histologically detectable signs of vascular changes in epineurial and endoneurial tissue, such as thickening of basal membranes, intima hyperplasia, and endothelial cell swelling. All PVD patients presented with end-stage PVD and previous food ulceration (2 of 5 had no ulcer at the time of biopsy, 2 had dry and 1 had wet gangrene of the toes). Three of 5 patients presented with popliteal or tibial PVD, 2 with femoral PVD. Two patients had had previous bypass operation, 2 had undergone percutaneous transluminal angioplasty, and 2 had had amputation of the fore foot.

Morphologically, 8 of 10 patients with diabetic polyneuropathy had a predominant axonal neuropathy, 1 showed mainly demyelination, and another showed an axonal-demyelinating neuropathy. Five of 10 patients had thickening of the perineurium and/or subperineurial edema, and 8 of 10 had vascular changes in the epineurial vessels, such as thickening of basal laminae, intima hyperplasia, and sclerosis. Reduction of myelinated fibers was mild in 1 of 10 , moderate in 8 of 10 , and strong in 1 of 10 .

The control group was formed by biopsies of sural nerves of 2 patients complaining of sensory and/or motor symptoms who underwent diagnostic biopsy but actually did not suffer from any neuromuscular disease, 4 patients with CMT type I (CMT-I), and 2 with CMT-II. None of the healthy controls had muscle weakness, sensory disturbances, or electromyographic or electroneurographic abnormalities, nor did they have histological alterations of the nerve as indicated by conventional light microscopy and immunohistochemical procedures for revealing and phenotyping of inflammatory cells. The diagnosis of CMT-I and CMT-II was established according to clinical and laboratory criteria (50). Semithin sections in CMT-I patients showed classic onion bulbs. Naked axons were also noted. Sparse fibers underwent myelin breakdown. In the 2 patients with CMT-II, myelinated fibers were strongly reduced, with prominent endoneurial fibrosis and regenerating clusters. Like in CMT-I, the perineurium and the vessels did not show light-microscopic changes. All patients investigated gave their informed consent. The study was approved by the Ethikkommission der Universität Erlangen-Nürnberg.

\section{Immunobistochemistry}

Tissue samples were frozen immediately after biopsy in isopentane and cooled in liquid nitrogen as previously described (14). The following antibodies diluted with $0.05 \mathrm{M}$ Tris buffer or PBS were used: polyclonal rabbit anti-CML $(1: 1,600)(37)$; polyclonal RAGE anti-goat $(1: 4,000)$ (provided by Mark Shearman, Merck Sharpe \& Dome Ltd.); polyclonal rabbit anti-NF-KBp65 (1:100); polyclonal rabbit anti-IL-6 (1:100) (Santa Cruz Biotechnology Inc.); monoclonal mouse anti-S100A8/A9 (clone Mac 387; 1:400) and monoclonal mouse anti-S100B (clone M 7221; 1:10) (both from DAKO Diagnostika GmbH); and anti-PGP9.5 (1:1,000) (Chemicon International Inc.). They were visualized using either the alkaline phosphatase anti-alkaline phosphatase (APAAP) immunostaining method (14) or peroxidase labeling techniques (24). Negative controls for the staining specificity of all primary antibodies were performed with nonimmune Ig instead of the specific antibody. Faint Hemalaun counterstaining was used to reveal cellular structures. Each section was independently examined by 2 of the authors, both unaware of the sample identity. Staining intensities were evaluated according to the following score: 0 , negative staining; 1 , weak staining intensity; 2 , moderate staining intensity; 3 , strong staining intensity. Median values of the respective results were obtained for statistical evaluation.

\section{Mouse models}

$\beta$-Globin transgenic mice. Mice transgenic for an NF- $\kappa \mathrm{B}$-driven $\beta$-globin reporter gene $(\operatorname{tg} 14)(33)$ were provided by Thomas Wirth (University of Ulm, Ulm, Germany). Eight-week-old mice were used throughout all experiments. One group was treated with STZ to develop diabetes (see below) and kept in the hyperglycemic state for 6 weeks with an average blood glucose level of $400 \mathrm{mg} / \mathrm{dl}$. Other groups of mice were left untreated or treated once with $1,000 \mu \mathrm{g}(500 \mu \mathrm{g}$ i.p., $500 \mu \mathrm{g}$ i.v. $)$ murine native albumin or AGE-albumin (characterized as previously described in detail; ref. 24) at time point 0 and kept for 6 days. In addition, some mice received sRAGE ( $25 \mu \mathrm{g} / \mathrm{mouse})(24)$, anti-RAGE antibodies ( $40 \mu \mathrm{g} /$ mouse) (24) at days 0 and 3 , or the antioxidant thioctic acid $(100 \mu \mathrm{g} / \mathrm{kg} / \mathrm{d})$ (51). At the end of the experiments, mice were sacrificed, and sciatic nerves were removed and immediately snap-frozen for further analysis. Mice were housed in groups of 4 mice per cage with a 12-hour/ 12-hour light/dark cycle and free access to food and water. Procedures in this study were approved by the Animal Care and Use Committee at the Regierungspräsidium Karlsruhe, Germany.

RAGE ${ }^{-/-}$mice. $\mathrm{RAGE}^{-/-}$mice constructed on an SVEV129×C57BL/6 (129/B6) background are viable and display normal reproductive fitness $(31,36)$. Experiments performed in the mixed background of RAGE-/and WT mice were repeated with $\mathrm{RAGE}^{-/-}$mice and WT littermates after 2-4 backcrosses to $\mathrm{C} 57 \mathrm{BL} / 6$ mice $\left(\mathrm{F}_{2}-\mathrm{F}_{4}\right)$ with similar results (data not shown). Diabetes induction was performed in 6-week-old 129/B6 WT controls (Taconic) as well as age- and gender-matched RAGE Re $^{-/}$mice. After the onset of diabetes, mice were kept in the hyperglycemic state for 6 months. Mice were housed individually with a 12-hour/12-hour light/ dark cycle and free access to food and water. Procedures in this study were approved by the Animal Care and Use Committees at the Regierungspräsidien Tübingen and Karlsruhe, Germany.

\section{Induction of diabetes using $S T Z$}

Eight-week-old $\beta$-globin mice or 6-week-old $\mathrm{RAGE}^{-/-}$or WT mice were used throughout the experiments. Diabetes was induced by i.p. administration of STZ at $60 \mathrm{mg} / \mathrm{kg}$, freshly dissolved in $0.05 \mathrm{M}$ sterile sodium citrate, $\mathrm{pH} 4.5$, on 6 subsequent days. Control animals received sodium citrate only. Diabetes was verified 16-25 days later by measurement of blood glucose levels in samples from the tail vein using ACCU-CHEK glucose sticks and a conventional Accutrend glucometer (Roche Diagnostics Corp.). In the first 2 weeks after onset of diabetes, blood glucose was measured daily. If glucose levels occasionally recovered, an additional STZ injection was given on days $25-27$. More than $90 \%$ of mice became 
diabetic within the first 4 weeks and were used throughout the experiments. As soon as blood glucose increased above $300 \mathrm{mg} / \mathrm{dl}$, individual supplementation with 1-2 U Insulin Semilente (40 U/ml; Novo Nordisc) was started. After blood glucose levels had stabilized, blood glucose was determined at least once a week for the first 2 months and thereafter every second week. The tight blood glucose control kept the individual blood glucose levels stable throughout the experiments. At the end of the experiments, mice were sacrificed with $\mathrm{CO}_{2}$, and both sciatic nerves were dissected, weighed, and snap-frozen in liquid nitrogen for measurement

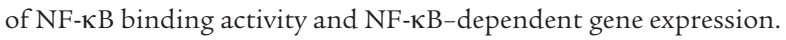

\section{EMSA}

Nuclear proteins were harvested as described elsewhere $(19,20,24)$ and assayed for transcription factor binding activity using the NF- $\mathrm{\kappa B}$ consensus sequence 5'-AGTTGAGGGGACTTTCCCAGGC-3' (binding region underlined). Specificity of binding was ascertained by competition with a 160-fold molar excess of unlabeled consensus oligonucleotides.

\section{RT-PCR}

RT-PCR was performed using $1 \mu \mathrm{g}$ total RNA as starting material. PCR conditions for $\beta$-globin and $\beta$-actin have previously been described in detail (24). For NF-кBp65 and murine IL- 6 the following primers and conditions were used: NF-кBp65 (p65 forward, 5'-GCTACAAGTGCGAGGGGC-3'; p65 reverse, 5'-GGGGTCTGCGTAGGGAGGG-3'): 1 cycle of $95^{\circ} \mathrm{C}$ for 360 seconds; 1 cycle of $94^{\circ} \mathrm{C}$ for 75 seconds, $52^{\circ} \mathrm{C}$ for 180 seconds, and $72^{\circ} \mathrm{C}$ for 60 seconds; 3 cycles of $94^{\circ} \mathrm{C}$ for $75 \mathrm{sec}-$ onds, $55^{\circ} \mathrm{C}$ for 180 seconds, and $72^{\circ} \mathrm{C}$ for 60 seconds; 40 cycles of $94^{\circ} \mathrm{C}$ for 60 seconds, $65^{\circ} \mathrm{C}$ for 60 seconds, and $72^{\circ} \mathrm{C}$ for 60 seconds; and 1 cycle of $72^{\circ} \mathrm{C}$ for 600 seconds; murine IL-6 (IL-6 forward, $5^{\prime}$-GATGCTACCAAACTGGATATAATC-3'; IL-6 reverse, 5'-GGTCCTTAGCCACTCCTTCTGTG-3'): 1 cycle of $94^{\circ} \mathrm{C}$ for 240 seconds; 1 cycle of $94^{\circ} \mathrm{C}$ for 30 seconds, $55^{\circ} \mathrm{C}$ for 120 seconds, and $72^{\circ} \mathrm{C}$ for 60 seconds; 2 cycles of $94^{\circ} \mathrm{C}$ for 30 seconds, $60^{\circ} \mathrm{C}$ for 45 seconds, and $72^{\circ} \mathrm{C}$ for 45 seconds; 28 cycles of $94^{\circ} \mathrm{C}$ for 30 seconds, $65^{\circ} \mathrm{C}$ for 45 seconds, and $72^{\circ} \mathrm{C}$ for 45 seconds; and 1 cycle of $72^{\circ} \mathrm{C}$ for 600 seconds. The PCR products were separated onto $1.5-2 \%$ agarose gels and visualized by ethidium bromide staining. Amplification of $\beta$-actin served as control for sample loading and integrity. Reactions lacking template RNA or avian myeloblastosis virus-reverse transcriptase served as internal controls.

\section{Isolation of DRG cells and ganglion cell culture}

DRG were removed from 6-month-old female $\mathrm{RAGE}^{-/-}$and WT control mice and then isolated and cultured basically as described by Stucky and Lewin (52). For each culture, 1 mouse was used. Nerve growth factor (mouse 7S; Sigma-Aldrich) was added to DMEM NUT MIX F-12 medium (Invitrogen Corp.), and cells were plated on coverslips coated with poly-L-ornithin and laminin (Sigma-Aldrich). Cells were incubated with native albumin or CML-albumin $(800 \mathrm{nM})$. Where indicated, 100 $\mu \mathrm{M}$ thioctic acid (dissolved in $\mathrm{NaOH}$; final concentration $0.1 \mu \mathrm{M}$ ) or $0.1 \mu \mathrm{M} \mathrm{NaOH}$, the solvent of thioctic acid (data not shown), was added on days 1,3 , and 5. Cells were fixed on day 5, and immunhistochemistry for activated NF-кBp65 was performed as previously described (24). Monoclonal anti-p65 antibodies, specific for active NF- $\mathrm{BB}$, were initially obtained from Boehringer Mannheim GmbH and were later obtained from Chemicon International Inc. Positivity for activated NF-кBp65 was evaluated semiquantitatively by examination of 10 visual fields (magnification, $\times 200$ ) of each coverslip ( 2 coverslips for each group) by 1 of the authors, who was unaware of the sample identity, using the following score: 0 , negative staining; 1 , weak staining intensity; 2 , moderate staining intensity; 3 , strong staining intensity.

\section{Measurement of pain perception}

Thermal nociception was studied using the hot-plate test with an electronically controlled hot-plate analgesia meter (Columbus Instruments) at $50^{\circ} \mathrm{C}$ and $55^{\circ} \mathrm{C}(38,39)$. Each mouse was removed from the hot plate when a jumping escape response occurred or hind paws were licked, or after a maximal cutoff time of 60 seconds $\left(50^{\circ} \mathrm{C}\right)$ or 50 seconds $\left(55^{\circ} \mathrm{C}\right)$ was reached. The latency until mice showed the first signs of discomfort (hind-paw lifting, licking, or shaking, and jumping) was recorded by 2 investigators (A. Bierhaus and P.M. Humpert). Five measurements, each taken 3 days apart, were averaged. Pilot experiments indicated that $\mathrm{C} 57 \mathrm{BL} / 6 \mathrm{WT}$ mice and $\mathrm{RAGE}^{-/}$mice were more sensitive in the hot-plate assay than $\beta$-globin transgenic mice. Therefore, the experiments with WT and $\mathrm{RAGE}^{-/-}$mice were performed at $50^{\circ} \mathrm{C}$, while the increased response latencies in $\beta$-globin mice required an increase of the assay temperature to $55^{\circ} \mathrm{C}$ in order to generate sharp results.

\section{Statistical analysis}

All results are expressed as mean \pm SEM. Unpaired, 2-tailed Student's $t$ tests were used in all comparisons; $P<0.05$ was considered to be statistically significant (denoted by single asterisks in the figures), and $P<0.005$ to be highly statistically significant (denoted by double asterisks in the figures). Pearson correlation was performed using the StatView program (SAS Institute Inc.).

\section{Acknowledgments}

We wish to thank T. Wirth for providing the $\beta$-globin transgenic mice and H.M. Meinck for measuring nerve conduction velocities. Anti-RAGE antibodies were kindly provided by M.A. Shearman. sRAGE was a generous gift from Aventis Pharma GmbH. This work was in part supported by grants from the Deutsche Forschungsgemeinschaft (Na 138/5-3 to P.P. Nawroth; DFG/SFB 405 to P.P. Nawroth, B. Arnold, and M. Schwaninger), the European Foundation for the Study of Diabetes (to A. Bierhaus), the German Diabetes Association (Christian Hagedorn Award to A. Bierhaus; research grant to P.M. Humpert), the European Commission (QLRT-1999-00584 to J.B. Schulz), the Bundesministerium für Forschung und Technik (to M. Kasper), Stiftung Verum (to P.P. Nawroth), the University of Heidelberg (to A. Bierhaus), and ASTA Medica GmbH (to A. Bierhaus). A.-M. Schmidt and D.M. Stern were supported by grants from the United States Public Health Service, the American Heart Association (New York affiliate), and the Juvenile Diabetes Research Foundation.

Received for publication February 6, 2003, and accepted in revised form October 7, 2004.

Address correspondence to: Angelika Bierhaus, University of Heidelberg, Department of Medicine I, Im Neuenheimer Feld 410, 69120 Heidelberg, Germany. Phone: 0049-6221-564752; Fax: 00496221-564754; E-mail: angelika_bierhaus@med.uni-heidelberg.de.

Portions of this work were presented at the 34th meeting of the German Diabetes Society in Frankfurt, Germany, in 1999; at the 10th International Symposium on the Autonomic Nervous System in Mauna Lani, Hawaii, USA, in 1999; at the Neurodiab Meeting of the European Association for the Study of Diabetes in Fiuggi, Italy, in 2000; and at the Annual Meeting of the American Diabetes Association in New Orleans, Louisiana, USA, in 2002.

Angelika Bierhaus and Karl-Matthias Haslbeck contributed equally to this work. 
1. Boulton, A.J. 1998. Lowering the risk of neuropathy, foot ulcers and amputations. Diabet. Med. 15(Suppl. 4):S57-S59.

2. Vinik, A.I., Park, T.S., Stansberry, K., and Pittenger, G.L. 2000. Diabetic neuropathies. Diabetologia. 43:957-973.

3. Greene, D.A., Stevens, M.J., Obrosova, I., and Feldman, E.L. 1999. Glucose-induced oxidative stress and programmed cell death in diabetic neuropathy. Eur. J. Pharmacol. 375:217-223.

4. Carrington, A.L., and Litchfield, J.E. 1999. The aldose reductase pathway and nonenzymatic glycation in the pathogenesis of diabetic neuropathy: a critical review for the end of the 20th Century. Diabetes Reviews. 7:275-299.

5. Ahlgren, S.C., and Levine, J.D. 1994. Protein kinase $\mathrm{C}$ inhibitors decrease hyperalgesia and C-fibre hyperexcitability in the streptozotocin-diabetic rat. J. Neurophysiol. 72:684-692.

6. Cameron, N.E., and Cotter, M.A. 1995. Neurovascular dysfunction in diabetic rats. J. Clin. Invest 96:1159-1163.

7. Zochodne, D.W., and Cheng, C. 1999. Diabetic peripheral nerves are susceptible to multifo$\mathrm{cal}$ ischemic damage from endothelin. Brain Res. 838:11-17.

8. Nagamatsu, M., et al. 1995. Lipoic acid improves nerve blood flow, reduces oxidative stress, and improves distal nerve conduction in experimental diabetic neuropathy. Diabetes Care. 18:1160-1167.

9. Schratzberger, P., et al. 2001. Reversal of experimental diabetic neuropathy by VEGF gene transfer. J. Clin. Invest. 107:1083-1092.

10. Hafer-Macko, C.E., Ivey, F.M., Gyure, K.A., Sorkin, J.D., and Macko, R.F. 2002. Thrombomodulin deficiency in human diabetic nerve microvasculature. Diabetes. 51:1957-1963.

11. Tomlinson, D.R., Fernyhough, P., and Diemel, L.T. 1996. Neurotropins and peripheral neuropathy. Philos. Trans. R. Soc. Lond. B Biol. Sci. 351:455-462.

12. Sima, A.A., et al. 2001. C-peptide prevents and improves chronic type I diabetic polyneuropathy in the BB/Wor rat. Diabetologia. 44:889-897.

13. Vlassara, H., Brownlee, M., and Cerami, A. 1981. Nonenzymatic glycosylation of peripheral nerve protein in diabetes mellitus. Proc. Natl. Acad. Sci. U.S. A. 78:5190-5192.

14. Haslbeck, K.M., et al. 2002. N(epsilon)-Carboxymethyllysine in diabetic and non-diabetic polyneuropathies. Acta Neuropathol. 104:45-52.

15. Sugimoto, K., Nizhizawa, Y., Horiuchi, S., and Yagihashi, S. 1997. Localization in human diabetic peripheral nerve of $\mathrm{N} \varepsilon$-carboxymethyllysine-protein adducts, an advanced glycation endproduct. Diabetologia. 40:1380-1387.

16. Mattson, M.P., and Camandola, S. 2001. NF-кB in neuronal plasticity and neurodegenerative disorders. J. Clin. Invest. 107:247-254.

17. Okamoto, K., Martin, D.P., Schmelzer, J.D., Mitsui, Y., and Low, P.A. 2001. Pro- and antiinflammatory cytokine gene expression in rat sciatic nerve chronic constriction injury model of neuropathic pain. Exp. Neurol. 169:386-391.

18. Vincent, A.M., Brownlee, M., and Russell, J.W. 2002. Oxidative stress and programmed cell death in diabetic neuropathy. Ann. N. Y. Acad. Sci. 959:368-383.

19. Bierhaus, A., et al. 1997. Advanced glycation end product-induced activation of NF- $\mathrm{KB}$ is suppressed by $\alpha$-lipoic acid in cultured endothelial cells. Diabetes.
46:1481-1490.

20. Hofmann, M.A., et al. 1999. Peripheral blood mononuclear cells isolated from patients with diabetic nephropathy demonstrate increased activation of the oxidative-stress sensitive transcription factor NF-KB. Diabetologia. 42:222-232

21. Haak, E.S., et al. 1999. The effect of alpha-lipoic acid on the neurovascular reflex in patients with diabetic neuropathy assessed by capillary microscopy. Microvasc. Res. 58:28-34.

22. Ziegler, D., et al. 1999. Treatment of symptomatic diabetic polyneuropathy with the antioxidant alpha-lipoic acid: a 7-month multicenter randomized controlled trial (ALADIN III study). ALADIN III Study Group. Alpha-Lipoic Acid in Diabetic Neuropathy. Diabetes Care. 22:1296-1301.

23. Ametov, A.S., et al. 2003. The sensory symptoms of diabetic polyneuropathy are improved with alpha-lipoic acid: the SYDNEY trial. Diabetes Care. 26:770-776.

24. Bierhaus, A., et al. 2001. Diabetes-associated sustained activation of the transcription factor nuclear factor-кB. Diabetes. 50:2792-2808.

25. Nishikawa, T., et al. 2000. Normalizing mitochondrial superoxide production blocks three pathways of hyperglycemic damage. Nature. 404:787-790

26. Brownlee, M. 2001. Biochemistry and molecular cell biology of diabetic complications. Nature. 414:813-820

27. Schiekofer, S., et al. 2003. Acute (2h) hyperglycemic clamp causes intracellular formation of carboxymethyllysine, activation of Ras, p42/p44 MAPK and NF- $\mathrm{KB}$ in peripheral blood mononuclear cells. Diabetes. 52:621-633.

28. Li, J., and Schmidt, A.M. 1997. Characterization and functional analysis of the promoter of RAGE, the receptor for advanced glycation end products. J. Biol. Chem. 272:16498-16506.

29. Schmidt, A.M., Yan, S.D., Yan, S.F., and Stern, D.M. 2001. The multiligand receptor RAGE is a progression factor amplifying immune and inflammatory responses. J. Clin. Invest. 108:949-955. doi:10.1172/ JCI200114002.

30. Poduslo, J.F., and Curran, G. 1992. Increased permeability across the blood-nerve barrier of albumin glycated in vitro and in vivo from patients with diabetic polyneuropathy. Proc. Natl. Acad. Sci. U. S. A. 89:2218-2222.

31. Constien, R., et al. 2001. Characterization of a novel EGFP reporter mouse to monitor Cre recombination as demonstrated by a Tie 2 Cre mouse line. Genesis. 30:36-44

32. Gonzalez-Martinez, T., Perez-Pinera, P., DiazEsnal, B., and Vega, J.A. 2003. S-100 proteins in the human peripheral nervous system. Microsc. Res. Tech. 60:633-638.

33. Lernbecher, T., Muller, U., and Wirth, T. 1993. Distinct NF-kappa B/Rel transcription factors are responsible for tissue-specific and inducible gene activation. Nature. 365:767-770.

34. Barnes, P.J., and Karin, M. 1997. Nuclear factor-кB: a pivotal transcription factor in chronic inflammatory diseases. N. Engl. J. Med. 336:1066-1071.

35. Flatters, S.J.L., Fox, A.J., and Dickenson, A.H. 2004. Nerve injury alters the effects of interleukin- 6 on nociceptive transmission in peripheral afferents. Eur. J. Pharmacol. 484:183-191.

36. Liliensiek, B., et al. 2004. Receptor for advanced glycation end products (RAGE) regulates sepsis but not the adaptive immune response. J. Clin. Invest. 113:1641-1650. doi:10.1172/JCI200418704.

37. Schleicher, E.D., Wagner, E., and Nerlich, A.G. 1997. Increased accumulation of the glycoxidation product $\mathrm{N}^{\varepsilon}$-(carboxymethyl)lysine in human tissues in diabetes and aging. J. Clin. Invest. 99:457-468.

38. Menendez, L., Lastra, A., Hidaldo, A., and Baamonde, A. 2002. Unilateral hot plate test: a simple and sensitive method for detecting central and peripheral hyperalgesia in mice. J. Neurosci. Methods. 113:91-97.

39. Chen, C.C., et al. 2002. A role for ASIC3 in the modulation of high intensity pain stimuli. Proc. Natl. Acad. Sci. U. S. A. 13:8992-8997.

40. Vinik, A.I., Erbas, T., Stansberry, K.B., and Pittenger, G.L. 2001. Small fiber neuropathy and neurovascular disturbances in diabetes mellitus. Exp. Clin. Endocrinol. Diabetes. 109(Suppl. 2):S451-S473.

41. Kislinger, T., et al. 1999. N(epsilon)-(carboxymethyl)lysine adducts of proteins are ligands for receptor for advanced glycation end products that activate cell signaling pathways and modulate gene expression. J. Biol. Chem. 274:31740-31749.

42. Kislinger, T., et al. 2001. Receptor for advanced glycation end products mediates inflammation and enhanced expression of tissue factor in vasculature of diabetic apolipoprotein E-null mice. Arterioscler. Thromb. Vasc. Biol. 21:905-910.

43. Lue, L.F., et al. 2001. Involvement of microglial receptor for advanced glycation endproducts (RAGE) in Alzheimer's disease: identification of a cellular activation mechanism. Exp. Neurol. 171:29-45.

44. Lezoulac'h, F., Sagara, Y., Holsboer, F., and Behl, C. 1998. High constitutive NF- $\kappa$ B activation mediates resistance to oxidative stress in neuronal cells. J. Neurosci. 18:3224-3232.

45. Flynn, M.D., and Tooke, J.E. 1995. Diabetic neuropathy and the microcirculation. Diabet. Med. 12:298-301.

46. Yeh, C.H., et al. 2001. Requirement for p38 and p44/p42 mitogen-activated protein kinases in RAGE-mediated nuclear factor-kappaB transcriptional activation and cytokine secretion. Diabetes. 50:1495-1504

47. Arancio, O., et al. 2004. RAGE potentiates Abetainduced perturbation of neuronal function in transgenic mice. EMBOJ. 23:4096-4105.

48. 1988. Consensus statement: report and recommendations of the San Antonio conference on diabetic neuropathy. American Diabetes Association American Academy of Neurology. Diabetes Care. 11:592-597.

49. Neundörfer, B. 1998. Klinik und Diagnose der Polyneuropathien. Dtsch. Med. Wochenschr. 23:1519-1522.

50. Dyck, P.J., Chance, P., Labedo, R., and Carney, J.A. 1993. Hereditary motor and sensory neuropathies. In Peripheral neuropathy. 3rd edition. P.J. Dyck et al., editors. W.B. Saunders Co. Philadephia, Pennsylvania, USA. 1094-1113.

51. Hounsom, L., Horrobin, D.F., Tritschler, H., Corder, R., and Tomlinson, D.R. 1998. $\alpha$-Lipoic acid-gamma linolenic acid conjugate is effective against multiple indices of experimental diabetic neuropathy. Diabetologia. 41:839-843.

52. Stucky, C.L., and Lewin, G.L. 1999. Isolectin B 4positive and -negative nociceptors are functionally distinct. J. Neurosci. 19:6497-6505. 